\title{
MIR10A Pre-miRNA
}

National Cancer Institute

\section{Source}

National Cancer Institute. MIR10A Pre-miRNA. NCI Thesaurus. Code C82698.

MIR10A pre-miRNA is an oligoribonucleotide that is encoded by the human MIR10A gene and has a role in the regulation of gene expression. 